\title{
Discussion Paper No. 13-013 \\ Intermediate Input Markets, ICT and Innovation in Germany: A Firm Level Analysis
}

Daniel Cerquera and Gordon J. Klein

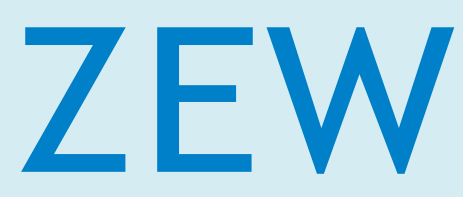

Zentrum für Europäische Wirtschaftsforschung $\mathrm{GmbH}$ Centre for European Economic Research 
Discussion Paper No. 13-013

\section{Intermediate Input Markets, ICT and Innovation in Germany: A Firm Level Analysis}

Daniel Cerquera and Gordon J. Klein

Download this ZEW Discussion Paper from our ftp server:

http://ftp.zew.de/pub/zew-docs/dp/dp13013.pdf

Die Discussion Papers dienen einer möglichst schnellen Verbreitung von neueren Forschungsarbeiten des ZEW. Die Beiträge liegen in alleiniger Verantwortung der Autoren und stellen nicht notwendigerweise die Meinung des ZEW dar.

Discussion Papers are intended to make results of ZEW research promptly available to other economists in order to encourage discussion and suggestions for revisions. The authors are solely responsible for the contents which do not necessarily represent the opinion of the ZEW. 


\section{Non-technical summary}

During the last 20 years developed economies have evidenced an increase in their expenditures on information and communication technologies (ICT), and there is ample evidence indicating that the diffusion of ICT has contributed to their productivity growth. This positive impact has been explained by the role of ICT as "enabling" technologies, allowing firms to optimize their internal organization, redesign production and commercial processes and introduce new products and services.

In the economic literature, ICT have been regarded as general purpose technologies (GPT). These technologies are viewed as drastic innovations characterized by their pervasive use in a wide range of economic sectors, as well as by their considerable potential for the development of complementary innovations and applications. In addition, given their technological complexity, the implementation of new GPT entails a process of experimentation subject to adoption externalities and knowledge spillovers. The former are evidenced when the attractiveness of a given technology is further increased when many firms use the same technology and experiment in the same direction (i.e. network effects), while the latter arise from the experience over time of other firms with the same or similar technologies.

In consequence, the process of adoption of ICT is a knowledge-intensive and costly process, whose success depends on a firm's own efforts, as well as on the nature of its interactions with other firms. This paper argues that some important economic interactions relevant for the diffusion of ICT take place in the intermediate input markets. More specifically, the paper empirically studies the impact of ICT on the economic performance at the firm level, explicitly considering the interaction of adopting firms with their suppliers, competitors and clients.

The results show that the adoption of ICT at the firm level is positively affected by the use of ICT downstream and upstream (i.e. by a firm's clients and suppliers). Moreover, the use of ICT upstream (i.e. by a firm's suppliers) negatively affects the extend of IT outsourcing at the firm level, suggesting a substitution effect between inputs provided by suppliers with an intense use of ICT and a firm's demand for external IT services. The paper also finds that the use of ICT within the intermediate input markets positively affects the efficiency of internal processes by increasing the cost reductions generated by the introduction of process innovations. 


\section{Das Wichtigste in Kürze}

Ziel der Studie ist es, den Einfluss der Einführung von Informations- und Kommunikationstechnologien (IKT) auf den Unternehmenserfolg zu untersuchen. Insbesondere wird die Interaktion zwischen dem IKT-anwendenden Unternehmen und seinen Kunden, Lieferanten und Wettbewerbern auf den Zwischenproduktmärkten analysiert. In erster Linie soll die Bedeutung von Anwendungsexternalitäten und Wissensspillover bei der Einführung von IKT auf Zwischenproduktmärkten in Deutschland identifiziert und quantifiziert werden. Dabei wird auch ihr Einfluss auf die beobachtbaren Unternehmensstrategien und ihr Gesamteffekt auf das Innovationsverhalten untersucht.

In der Literatur werden IKT als sogenannte "General Purpose Technologies” (GPT), also als Querschnittstechnologien angesehen. GPT sind einschneidende Innovationen, die durch ihren durchdringenden Einfluss auf eine Vielzahl von Wirtschaftssektoren gekennzeichnet sind. Sie schaffen ein Potential für neue komplementäre Innovationen. Zusätzlich schließt die Implementierung dieser GPT einen Prozess des Experimentierens mit ein, der wiederum von Anwendungsexternalitäten und Wissensspillover innerhalb der verschiedenen Sektoren gekennzeichnet ist. Daher ist der Erfolg der IKT-Implementierung nicht nur von den Anstrengungen des einzelnen Unternehmens, sondern auch von der Art und Weise der Interaktion mit anderen Firmen abhängig. Verschiedene dieser wichtigen wirtschaftlichen Interaktionen finden in den Zwischenproduktmärkten statt, indem neue Methoden und Technologien zur Entwicklung neuer Produkte und Dienstleistungen fortwährend ausgetauscht, getestet und ersetzt werden.

Die bestehende Forschung zu den GPT konzentriert sich bisher auf eine sektorale Betrachtung und lässt die Interaktionen und Anreizstrukturen auf Unternehmensebene außen vor. Diese Studie trägt zur Analyse des wirtschaftlichen Einflusses von IKT auf Unternehmensebene bei und berücksichtigt Zwischenproduktmärkte aus der Perspektive der GPT-Theorie. Die Ergebnisse zeigen, dass die Intensität der IKT-Nutzung auf Firmenebene (IKT-Infrastruktur und -Anwendungen) positiv von der IKT-Nutzung der Zulieferer und Kunden beeinflusst wird. Dieses Ergebnis weist darauf hin, dass Anwendungsexternalitäten der IKT-Nutzung innerhalb der Lieferkette vorliegen. Darüber hinaus weisen die Ergebnisse auf komplexe Wissensspillover hin, die Unternehmensstrategien und -erfolg beeinflussen. Zum Beispiel hat die IKT-Intensität der Zulieferer einen positiven Einfluss auf die Innovationsaktivitäten von Firmen, aber einen negativen Effekt auf deren IT-Outsourcing. 


\title{
Intermediate Input Markets, ICT and Innovation in Germany: A Firm Level Analysis
}

\author{
Daniel CERQUERA*
}

Gordon J. KLEIN ${ }^{\dagger}$

February 27, 2013

\begin{abstract}
This paper studies the impact of the adoption of ICT on the economic performance at the firm level, considering explicitly the interaction of adopting firms within the intermediate input market in Germany. The paper identifies and quantifies the importance of adoption externalities and knowledge spillovers inherent in the introduction of ICT. The results show that the adoption of ICT at the firm level is positively affected by the use of ICT downstream and upstream (i.e. by a firm's clients and suppliers). Moreover, the use of ICT upstream (i.e. by a firm's suppliers) negatively affects the extend of IT outsourcing at the firm level, suggesting a substitution effect between inputs provided by suppliers with an intense use of ICT and a firm's demand for external IT services. The paper also finds that the use of ICT within the intermediate input markets positively affects the efficiency of internal processes by increasing the cost reductions generated by the introduction of process innovations.
\end{abstract}

Keywords: Information and Communication Technologies, General Purpose Technologies, Intermediate Input Markets, Innovation, Firm Level Data.

JEL Classification: D22, L25, O32.

\footnotetext{
${ }^{*}$ cerquera@zew.de. Centre for European Economic Research (ZEW), Mannheim, Germany. Research Group Information and Communication Technologies. Corresponding author.

†klein@dice.uni-duesseldorf.de. Duesseldorf Institute for Competition Economics (DICE). University of Duesseldorf. We would like to thank Irene Bertschek, François Laisney, Mark McCabe, Jörg Ohnemus and Martin Peitz for helpful comments and suggestions, as well as seminar participants in Mannheim, Birmingham and Düsseldorf. Financial support by the Thyssen Stiftung is gratefully acknowledged. For further information on projects of the authors see www.zew.de/staff_dce as well as the ZEW annual report on www.zew.de/en. All errors are ours.
} 


\section{Introduction}

During the last 20 years developed economies have evidenced an important increase in their expenditures on information and communication technologies (ICT), and there is ample evidence indicating that the diffusion of ICT has contributed significantly to their productivity growth. ${ }^{1}$ This positive impact has been explained by the role of ICT as "enabling" technologies, allowing firms to optimize their internal organization, redesign production and commercial processes and introduce new products and services. $^{2}$ In consequence, the adoption and implementation of ICT has been at the core of the economic policy programs across developed nations during the last years.

In the economic literature, ICT have been regarded as general purpose technologies (GPT). These technologies are viewed as drastic innovations characterized by their pervasive use in a wide range of economic sectors, as well as by their considerable potential for the development of complementary innovations and applications. ${ }^{3}$ In addition, given their technological complexity, the implementation of new GPT entails a process of experimentation subject to adoption externalities and knowledge spillovers. The former are evidenced when the attractiveness of a given technology is further increased when many firms use the same technology and experiment in the same direction (i.e. network effects), while the latter arise from the experience over time of other firms with the same or similar technologies.

As a result, the process of adoption, implementation and diffusion of GPT in general, and ICT in particular, is a knowledge-intensive and costly process, whose success depends on a firm's own efforts, as well as on the nature of its interactions with other firms. In this paper we argue that some important economic interactions relevant for the diffusion of ICT take place in the intermediate input markets. That is, in the markets for materials and inputs other than labor and capital. In these markets new methods and technologies are continuously exchanged, tested and replaced for the development of new products and services. Therefore, the interactions in the intermediate input markets may be determinant in the development of ICT solutions.

\footnotetext{
${ }^{1}$ See Draca et al. (2007) and Jorgenson et al. (2008)

${ }^{2}$ The term "enabling technologies" was coined by Bresnahan and Trajtenberg (1995) in reference to drastic innovations that open up new opportunities rather than offering complete, final solutions.

${ }^{3}$ See Bresnahan and Trajtenberg (1995), Helpman (1998), David and Wright (2003), Lipsey et al. (2005) and Jovanovic and Rousseau (2005).
} 
This paper empirically studies the impact of ICT on the economic performance at the firm level, explicitly considering the interaction of adopting firms with their suppliers, competitors and clients in the intermediate input market. The analysis is based on a representative survey on detailed firm characteristics, use of ICT and economic performance of the German manufacturing and service sector (ZEW ICT Survey), as well as on the input-output tables from the German Statistical Office.

More specifically, the paper identifies and quantifies the importance of the adoption externalities and knowledge spillovers inherent in the introduction of ICT within the German intermediate input market, their impact on observed firm strategies and their overall effect on the innovative behavior at the firm level. Moreover, the paper contributes to the discussion on the determinants of the firm strategies that promote or hinder the full exploitation of the benefits of the introduction of ICT from the perspective of economic policy.

Two main reasons motivate the emphasis on the intermediate input markets. On the one hand, from input-output tables it is evident that for any economic sector, the expenditures in intermediate inputs (i.e. materials and inputs other than capital and labor) are a substantial portion of total input expenditures. ${ }^{4}$ Moreover, the economic literature has shown that the explanation of observed economic fluctuations (i.e. comovements in aggregate output and employment) requires the introduction of intersectoral linkages from the intermediate input market in order to accommodate the existence of independent and specific sectoral shocks. ${ }^{5}$ Therefore, intermediate input markets are not only important in volume, but also constitute a fundamental part of economic growth. ${ }^{6}$

On the other hand, given that unlike labor, intermediate inputs are reproducible and unlike capital, they depreciate completely within an accounting period, intermediate inputs exhibit a flexibility that allows firms to rapidly adapt to unexpected market contingencies. In this paper we argue that given their economic relevance within the development of products and services and their inherent flexibility, intermediate input markets are a major field in which firms experiment with the introduction of new ICT. In sum, this paper attempts to uncover the contribution of the intermediate input

\footnotetext{
${ }^{4}$ According to the German Statistical Office, in 2009 the average share of intermediate inputs of gross output in German industries was $50.3 \%$. The same pattern is observed in other industrialized economies.

${ }^{5}$ See Lucas (1981), Hornstein and Parschnik (1997), and Kim and Kim (2006).

${ }^{6}$ See Jones (2011).
} 
markets to the economic gains of the introduction of ICT.

The analysis is divided into three parts. The first part studies the adoption of ICT and explicitly considers the role of adoption externalities within the intermediate input market. The second part studies the impact of ICT adoption on firm strategies, considering the presence of knowledge spillovers in the relationships between adopting firms and suppliers, competitors and clients. Finally, the last part analyzes the impact of ICT on overall economic performance at the firm level in terms of innovative activity.

The results show strong evidence of adoption externalities. That is, the adoption of ICT at the firm level is positively affected by the use of ICT downstream and upstream (i.e. by a firm's clients and suppliers). Moreover, regarding the role of knowledge spillovers the paper shows that the use of ICT upstream (i.e. by a firm's suppliers) negatively affects the extend of IT outsourcing at the firm level, suggesting a substitution effect between inputs provided by suppliers with an intense use of ICT and a firm's demand for external IT services. The paper also finds that the use of ICT within the intermediate input markets positively affects the efficiency of internal processes by increasing the cost reductions generated by the introduction of process innovations.

The paper contributes to the economic literature on two main areas. The first area corresponds to the level of aggregation used in the present paper. The empirical analysis proposed in this paper is presented at the firm level. Even though there is an extensive literature on the economic impact of ICT at this level of aggregation, to the best of our knowledge, there are no studies considering the specific role of intermediate input markets in the introduction of ICT. Moreover, a great proportion of the literature documenting the economic impact of ICT is developed from an aggregate level by means of a growth accounting approach.

In addition, given the important heterogeneity existing at the firm level, the sources of ICT benefits might be firm-specific, requiring a detailed description of firms' characteristics and strategies. The approach followed in this paper provides the adequate level of detail to investigate not only the sources of ICT-related productivity gains, but the firm strategies that promote and enhance such gains.

The second area that reflects the contributions of the paper corresponds to the interaction between data on different levels of aggregation. Given that the main source of information of the intermediate input market is provided by the input-output tables 
computed by the German Statistical Office, the analysis can also incorporate different sources of information at the industry level. In consequence, in addition to the detailed information contained in the ZEW ICT Survey at the firm level, the paper contributes to the analysis of the links between micro and macroeconomic levels in explaining the impact of ICT on economic performance. This area of research is particularly relevant for policy purposes given that the results of microeconomic analyses entail the potential to clarify the evidence at the macroeconomic level.

The paper is organized as follows. The next section provides the literature review. The third section describes the empirical strategy followed in the paper. In particular, it attempts to identify and quantify the importance of the adoption externalities and knowledge spillovers inherent in the introduction of ICT within the German intermediate input market, their impact on observed firms' strategies and their overall effect on innovative behavior. The fourth section presents the results of the paper. The last section concludes.

\section{Related Literature}

This paper is related to three main strands of literature. The literature on information and communication technologies (ICT) as general purpose technologies (GPT) serves as the conceptual basis for the analysis. On the empirical side, the paper is related with the extensive literature on the economic impact of ICT at the aggregate level and at the firm level. Even though a small portion of this literature has considered the role of spillovers and externalities in the adoption of ICT, the role of the intermediate input markets has been not considered yet. Thus, the paper will additionally draw on the literature on intermediate input markets. The explicit introduction of intermediate input markets represents the main contribution of this paper to the economic literature on the economic impact of ICT. This section draws heavily from the arguments presented in the original project proposal.

The GPT approach provides the foundations for the empirical analysis presented in this paper. Specifically, a GPT is defined as a drastic innovation that has the potential for pervasive use in a wide range of economic sectors in ways that dramatically change their modes of operation. In this context the role of "innovational complementarities" receives particular attention. That is, not only are ICT used for a great variety 
of activities and purposes, but they also create new possibilities for the development of innovations, products and services that were previously not feasible. As a consequence, the full potential of the adoption of ICT is derived not only from its use, but also by the complementary effects among sectors and activities.

The seminal work by Bresnahan and Trajtenberg (1995) defines the notion of GPT. Specifically, they highlight the importance of two types of spillovers during the diffusion process of a GPT: i) between the producing sector of the GPT and the application sectors; and ii) across the application sectors. The first type arises from the difficulties that a GPT inventor may have in appropriating the fruits of her invention. When institutional conditions prevent full appropriation, the GPT is effectively underpriced and therefore undersupplied. The second type stems from the fact that, since the application sectors are not coordinated, each sector conditions its expansion on the available GPT. But if they coordinated a joint expansion, they would raise the profitability of the GPT and encourage its improvement.

However, the objective of Bresnahan and Trajtenberg (1995) is to show that the existence of spillovers in the adoption of a GPT might lead to economic inefficiencies, given that such spillovers are not fully internalized. For the purposes of this paper, the main message of Bresnahan and Trajtenberg (1995) is that the process of adoption of a GPT is slow and difficult, and requires the interaction of different sectors.

Helpman and Trajtenberg (1998a) extend this analysis and develop a formal framework that describes in detail how a GPT works and how its impact evolves over time. They build their approach as an endogenous growth model that depicts the impact of GPT in two stages. In the first stage, the GPT is adopted and complementary innovations are being developed but not fully implemented. In this stage, output as well as overall productivity might be negatively affected because the required knowledge is being developed. In the second stage, the model shows how the economy benefits from the complementary innovations and how the adoption of GPT generates important productivity gains.

The empirical strategy followed in the paper mirrors the framework presented in Helpman and Trajtenberg (1998a). The empirical investigation is divided into an analysis of the adoption of ICT with a focus on the spillovers and firm strategies, followed by an analysis of the impact of the adoption of ICT where the economic impact of ICT is assessed. 
A further extension of the model is presented in Helpman and Trajtenberg (1998b) who show how some sectors benefit more from the adoption of GPT than others. Meanwhile, the endogenous growth theory followed in Helpman and Trajtenberg (1998a, $1998 b$ ) is silent about the specific role of intermediate input markets and the strategies at the firm level. This paper complements this literature by performing such an analysis at the theoretical, as well as the empirical level.

In a related work, Aghion and Howitt (1998) argue that the model by Helpman and Trajtenberg (1998a, 1998b) does not provide an empirically accurate description of the initial reduction in output and productivity. Their model accounts for a larger initial downturn and provides an alternative explanation of why some sectors benefit more from an adoption of GPT than others. In sum, the GPT literature exhibits several features useful for the objectives of the paper. On the one hand, it is possible to derive concise empirical implications from this formal framework. On the other hand, the GPT theory allows the analysis of the drivers and consequences of ICT at a macro level that can rationalize the existing empirical results at this level of aggregation.

From an empirical perspective, Draca et al. (2007) present a comprehensive survey on the impact of ICT on economic performance. In particular, by reviewing empirical results at the macro, as well as the microeconomic level, they summarize some clear results in the literature. From a macroeconomic perspective, they conclude that ICT has been a source of the productivity growth observed in the U.S. since 1995, although the main contribution was evidenced since the year 2000. This is consistent with the GPT view that states that the benefits of the introduction of new technologies like ICT is not immediate, but requires some time in order to develop their full potential.

In their survey, Draca et al. (2007) discuss the fact that Europe has not fully benefited (yet) from the adoption of ICT in terms of productivity growth. As also discussed in Blanchard (2004), the European ICT-using sector has still to exploit the potential of the introduction of ICT. This view is consistent with the GPT approach followed in the present paper. Draca et al. (2007) additionally present some recent work that attempts (unsuccessfully) to measure the extent of ICT-related spillovers at the macroeconomic level, discussing the econometric challenges of this type of analysis at such level of aggregation.

From a microeconomic perspective, Draca et al. (2007) document a positive and robust relationship between ICT adoption and productivity. Moreover, they highlight 
the role of reorganizations at the firm level in order to exploit the benefits of ICT. This result motivates the emphasis of the present paper on the impact of ICT adoption on firm strategies. In addition, they comment on the absence of significant results in the analysis of spillover effects in the existing literature at the firm level. This paper argues that most of the spillovers and externalities are transmitted through the intermediate sector market that has not been analyzed in the literature surveyed in Draca et al. (2007).

On the methodological side, this paper is related with the literature that studies the transmission of knowledge spillovers from research and development (R\&D) expenditures. For instance, Bloom et al. (2007) analyze in detail how knowledge spillovers are generated in the U.S. manufacturing sector using a game theoretical framework that accounts for competitive pressure at the firm level. In addition to the identification of spillover effects in a production function framework, the analysis presented in Bloom et al. (2007) is relevant for the present paper as they discuss the benefits and problems of different approaches to measure spillovers.

Finally, this paper is related with the literature on the role of intermediate inputs markets. In general, standard neoclassical macroeconomic models do not consider these markets explicitly. Given that their focus is on the evolution of overall valueadded in the economy (i.e. GDP), intermediate inputs can be ignored because their contribution is included in the prices of final goods. Important exceptions include Long and Plosser (1983), Basu (1995), Ciccone (2002) and Jones (2011) who consider particular situations that emphasize the role of intermediate inputs in economic growth.

At the firm level, the industrial organization literature on vertical relations extensively studies the role of input (downstream) markets and their interaction with final (upstream) producers. Katz (1989), Holmstrong and Tirole (1989), Joskow (2006), and Rey and Tirole (2007) present surveys on different aspects of the wide spectrum of issues that arise in the analysis of vertical relations. In particular, this literature has been concentrated on the specific contractual features of the downstream-upstream relation, paying special attention to firm level strategies and their implications for antitrust and competition policy. This paper borrows substantially from this literature in order to describe the role of intermediate input markets and firm strategies in the analysis of the economic impact of ICT. 


\section{Empirical Approach}

\subsection{Empirical Strategy and Data}

We divide the empirical analysis in two parts. In the first part, we estimate the role of adoption externalities in the use of ICT within the intermediate input markets. The research questions considered in this part include: i) Does the intensity of ICT use of a given industry suppliers affect the intensity of ICT use of the final producers? ii) Is there any impact in the opposite direction?

In the second part, we analyze the role of knowledge spillovers. That is, we consider whether the use of ICT within the intermediate input markets has affected the adoption of specific firm strategies and/or the innovative output of German firms. The research questions included in this part are: i) What strategies adopted by a given industry suppliers (i.e. IT outsourcing) are correlated with more ICT use by final producers? ii) Is the innovative activity of a given industry suppliers influenced by the intensity of ICT use of the final producers?

More specifically, the two parts can be summarized as follows:

$$
\begin{aligned}
I C T_{i, j} & =f\left(I C T_{D}, I C T_{U}, X\right) \\
y_{i, j} & =g\left(I C T_{D}, I C T_{U}, X\right),
\end{aligned}
$$

In equation (1), we consider the role of adoption externalities. $I C T_{i, j}$ represents the use of ICT for firm $i$ that belongs to economic sector $j$. In order to estimate the impact of adoption externalities, we relate the use of ICT in firm $i$ with the the use of ICT of that firm's clients and suppliers. Following the standard concepts used in the economics literature, the former is labeled as the use of ICT downstream and the latter as the use of ICT upstream. Accordingly, the variable $I C T_{D}$ measures the use of ICT downstream (from the perspective of firm $i$ ). Similarly, we relate the use of ICT in firm $i$ with the use of ICT upstream with the corresponding variable $I C T_{U}$. In this relationship we control for additional variables, $X$, that can affect the adoption and implementation of ICT at the firm level. We assume the function $f($.) to be linear. Below we describe the variables included and the details on how $I C T_{D}$ and $I C T_{U}$ are calculated. 
In equation (2), we consider the role of knowledge spillovers. We are interested in analyzing whether the potential presence of adoption externalities in the use of ICT within the intermediate input markets has affected the market strategies employed by German firms and/or whether their innovative output has been influenced. More specifically, $y_{i, j}$ represents either a given strategy for firm $i$ (e.g. IT Outsourcing) or a measure of its innovative output (e.g. cost reductions from introducing process innovations) and, as in the first part, the analysis attempts to uncover the role of the use of ICT downstream and upstream. We assume the function $g($.$) to be linear. The set of$ variables included in the analysis are described in detail below.

The analysis is based on firm level data from the ZEW ICT Survey. This is a business survey is carried out by the Centre for European Economic Research (ZEW) that contains detailed information on the economic characteristics, performance and ICT use by a representative sample of the German manufacturing and service sectors. In particular, we use the information contained in the 2004 and 2007 waves with information for the years 2003 and 2006, respectively. In order to consider the role of the intermediate input markets we complement the information with the input-output tables for the German Statistical office for the year 2003.

More specifically, in order to capture the role of the use of ICT within the intermediate input market the analysis proceeds as follows. Each one of the firms present in the ZEW ICT Survey is allocated to an industry based on the product that represents its main source of sales. The set of industries that a firm can be assigned to is taken from the standard classification of economic activity in the European Community (NACE). Given that the information on the input-output tables from the German Statistical Office uses the same classification (i.e. NACE), it is possible to identify the relationships between a given firm's industry and all other industries in the German manufacturing and service sectors.

Moreover, aggregating the rich information on the ZEW ICT Survey using the standard industry classification mentioned before and controlling for potential sample bias, the ZEW ICT Survey provides a way to obtain unique and representative information of the ICT infrastructure and the industry level for Germany. This is the information exploited in the analysis and corresponds to the main source of the following results.

Table 1 reports the summary statistics of the available data from the ZEW ICT Survey, showing the evolution between 2003 and 2006 of the main variables used in the 
analysis. More specifically, it provides a summary of the ICT infrastructure of the surveyed firms for 2003. In that year and as a measure of the intensity of ICT use, on average, $48 \%$ of the employees were working mainly with a PC. Regarding the use of specific ICT applications, the adoption of Enterprise Resource Planning (ERP), Supply Chain Management ( $S C M$ ) and Customer Relationship Management (CRM) systems were adopted by $65 \%, 44 \%$ and $52 \%$ of the surveyed firms, respectively. Moreover, the utilization of a Business-to-Business application (B2B) was evidenced in $48 \%$ of the firms.

Table 1 also shows how, on average, the intensity of ICT use remained at $48 \%$ of employees working mainly with a PC in 2006. With respect to the ERP, SCM and CRM applications the adoption rates were 58\%, 37\% and 47\%, respectively. Interestingly, considering specific firm strategies, the data show that for the German firms, on average, $53 \%$ of the firms adopted $B 2 B$ and $35 \%$ of the internal IT intensive tasks were outsourced to external IT service providers in 2006. Regarding the value of innovative output available in the ZEW ICT Survey, German firms were able to increase their sales by $14 \%$ in 2006 as a result of the product innovations introduced during the period 2004-2006. Similarly, the process innovations introduced during the same period allowed the surveyed firms the reduce costs by $6 \%$ in 2006 .

\subsection{Part I: ICT and Adoption Externalities}

In order to analyze the presence of adoption externalities in the use of ICT within the intermediate input markets, we separately estimate the role of the use of ICT of a firm's clients (or use of ICT downstream) and the firm's suppliers (or use of ICT upstream). More specifically, we are interested in the estimation of the following equation describing the use of ICT at the firm level and the role of the use of ICT downstream:

$$
I C T_{i, j, t}=\beta_{0}+\beta_{1} I C T_{D, j, t-1}+\beta_{2} I C T_{i, j, t-1}+\beta_{3} X_{i, j, t-1}+\beta_{4} Z_{j, t-1}+\epsilon_{t}
$$

where $I C T_{i, j, t}$ represents the use of ICT for a firm $i$ that belongs to economic sector $j$. Throughout the analysis $t=2006$ and $t-1=2003$ given our available data. We also experiment with a large set of ICT variables taken from the ZEW ICT Survey and described below. Importantly, $I C T_{D, j, t-1}$ is a measure that summarizes the use of ICT 
by firm $i$ 's clients (i.e downstream). This variable is defined as follows:

$$
\begin{aligned}
I C T_{D, j, t-1} & =\sum_{k=1}^{K} \theta_{j, k}^{D} I C T_{k, t-1}, \\
\theta_{j, k}^{D} & =I O_{j, k, t-1} / \sum_{k}^{K} I O_{j, k, t-1},
\end{aligned}
$$

where $I C T_{D, j, t-1}$ is the use of ICT downstream viewed from the perspective of industry $j$ in 2003. Note that $I C T_{D, j, t-1}$ is a weighted average of an industry-specific variable $I C T_{k, t-1}$ with weights $\theta_{j, k}^{D}$, with $k \in\{1,2, \ldots, K\}$ defining the set of industries considered in the analysis. In general, the variable $I C T_{k, t-1}$ is constructed aggregating selected ICT information available in the ZEW ICT Survey at the industry-level, controlling for sampling bias.

The weights $\theta_{j, k}^{D}$ are calculated using the information of the input-output tables from the German Statistical Office that describe the proportion of output of a given sector used as input for all sectors in the economy (row information). Note that the vector of weights $\theta_{j, k}^{D}$ is industry-specific (i.e. $j$ is fixed in equations (4) and (5)). More specifically, $I O_{j, k, t-1}$ represents the entry $(j, k)$ in the input-output matrix $I O$ for 2003. That is, $I O_{j, k, t-1}$ is the output of industry $j$ that is used as an input in industry $k$ (i.e. $k$ is a downstream industry viewed from the perspective of industry $j$ ). Note that this definition implies that the weights $\theta_{j, k}^{D}$ only consider the output that is used as inputs domestically.

In addition, $I C T_{i, j, t-1}$ in equation (3) describes the existing ICT infrastructure in firm $i, X_{i, j, t-1}$ is a vector that contains firm-specific control variables, $Z_{j, t-1}$ is a vector with industry-specific controls and $\epsilon_{t}$ is normally distributed error term. This equation is estimated using OLS with clustered standard errors to allow for intra-industry correlation in the error term.

Similarly, and with a slight abuse of notation, the analysis of the role of the upstream market is captured by:

$$
I C T_{i, j, t}=\beta_{0}+\beta_{1} I C T_{U, j, t-1}+\beta_{2} I C T_{i, j, t-1}+\beta_{3} X_{i, j, t-1}+\beta_{4} Z_{j, t-1}+\epsilon_{t},
$$


with

$$
\begin{aligned}
I C T_{U, j, t-1} & =\sum_{k=1}^{K} \theta_{j, k}^{U} I C T_{k, t-1}, \\
\theta_{j, k}^{U} & =I O_{k, j, t-1} / \sum_{k}^{K} I O_{k, j, t-1},
\end{aligned}
$$

where the definition of the variables and the source of the information is the same as in the downstream case.

\subsection{Part II: ICT and Knowledge Spillovers}

The analysis of the role of knowledge spillovers due to the adoption of ICT in the German intermediate input markets is divided in two parts. The first part considers the impact of the use of ICT (upstream) on specific firm strategies. As has been frequently highlighted in the literature, the adoption of ICT requires important and sometimes radical reorganizations at the firm level. This process of reorganization implies costs that include the contracting of ICT consultants, new managers and/or retraining of existing employees. Moreover, given the complexity of ICT solutions, some of the strategies might include the outsourcing of particular internal processes. Therefore, we start the analysis with the impact of the use of ICT within the intermediate input markets on the proportion of IT incentive tasks outsourced by German firms. In particular, our estimation equation can be described as:

$$
y_{i, j, t}=\beta_{01}+\beta_{1} I C T_{U, t-1}+\beta_{2} I C T_{i, j, t-1}+\beta_{3} X_{i, j, t-1}+\beta_{4} Z_{j, t-1}+\epsilon_{t},
$$

where $y_{i, j, t}$ is the proportion of IT intensive tasks outsourced by German firms in 2006. As before, $I C T_{U, j, t-1}$ is the use of ICT upstream viewed from the perspective of industry $j$ in 2003. $I C T_{i, j, t-1}$ in equation (9) describes the existing ICT infrastructure in firm $i, X_{i, j, t-1}$ is a vector that contains firm-specific control variables, $Z_{j, t-1}$ is a vector with industry-specific controls and $\epsilon_{t}$ is normally distributed error term. This equation is estimated using OLS with clustered standard errors to allow for intra-industry 
correlation in the error term.

The second part corresponds to the impact of the use of ICT (downstream and upstream) on the innovative output. That is, we analyze whether the use of ICT within the intermediate input markets generated knowledge spillovers that affected the innovation capabilities of the surveyed firms. In this case, we use two alternative dependent variables, $y_{i, j, t}$. First, we use the value of product innovations measured as the increase in sales in 2006 as a result of the product innovations introduced during the period 2004-2006. We also use the value of process innovations measured as reduction in costs in 2006 from the introduction of process innovations during the same period. The analysis is performed using OLS with clustered standard errors to allow for intra-industry correlation in the error term.

\section{Results}

\subsection{ICT and Adoption Externalities}

In order to analyze the role of adoption externalities in the use of ICT within the German intermediate input markets, we estimate first equation (3) considering the impact of the use of ICT downstream for alternative measures measures of ICT use (i.e. $I C T_{i, j, t}$ ) at the firm level. Subsequently, we analyze the effect of the use of ICT upstream, following the same approach. Table 2 presents the results of the estimation of (3) where our dependent variable $I C T_{i, j, t}$ corresponds to the intensity of ICT use at the firm level measured as the percentage of employees working (mainly) with a PC. We are interested in parameter $\beta_{1}$ in equation (3). That is, the impact of $I C T_{D, j, t}$ that corresponds to the intensity of ICT use downstream.

The estimations show an important correlation between the intensity of ICT use at the firm level in Germany and the intensity of ICT use observed downstream (i.e. by a firm's clients). In particular, column (1) indicates a considerable positive and significant effect (coef. 0.5211; std. err. 0.1137). Even though the goodness of fit is relatively high $\left(R^{2}=0.39\right)$, this specification does not consider additional relevant firm characteristics that can influence the impact of the intensity of ICT use observed downstream. Column (2) introduces a lagged measure of the intensity of ICT use in order to control for the existing ICT infrastructure within the firm. Not surprisingly, the analysis reveals 
a large, positive and significant effect (coef. 0.6213; std. err. 0.0383). In turn, the effect of the intensity of ICT use downstream is considerably reduced, although it remains large and significant at the $5 \%$ level (coef. 0.1889; std. err. 0.0638). As expected, the introduction of information regarding the firms' ICT infrastructure increases the goodness of fit to $R^{2}=0.62$.

Columns (3) and (4) extend the analysis by introducing information regarding the presence of specific ICT applications in the surveyed firms. In particular, we consider the role of Supply Chain Management $(S C M)$, Customer Relationship Management $(C R M)$ and Enterprice Resource Planning (ERP) systems. The results show a positive and significant impact of SCM and CRM without affecting the results obtained in column (2). That is, not surprisingly, the presence of SCM and CRM at the firm level is positively correlated with the intensity of ICT use. Still, the coefficients on the existing (lagged) ICT infrastructure and the intensity ICT use downstream remain positive and significant, suggesting the existence of positive adoption externalities. In addition, we control in columns (5) and (6) for exporting behavior (Export Activity) and firm size (Total Employees (in Logs.)) in order to consider the role of specific firms characteristics. The results remain unchanged. All specifications presented in Table 2 include industry dummies and a location dummy indicating whether the firm is located in east Germany.

The results presented in Table 2 indicate a strong correlation between the intensity of ICT use at the firm level and the intensity of ICT use by the firms' clients, suggesting the presence of adoption externalities within the intermediate input market in Germany. Using the data available in the ZEW ICT Survey, we further analyze whether such adoption externalities are also present with the use of specific ICT applications. Table 3 considers the case of Supply Chain Management software (SCM). That is, we are interested on whether the adoption of $S C M$ by a firm's clients influenced the adoption of SCM by that firm. Using the same specifications presented in Table 2, the results show a strong correlation between the two variables with a coefficient for the adoption of SCM downstream ranging from 0.5337 (std. err. 0.1577) in column (6) to 0.7840 (std. err. 0.1416) in column (1). This result is not surprising. It states that a firm was more likely to have adopted SCM by 2006 if, on average, firms further down the supply chain have also adopted SCM by 2003.

Tables 4 and 5 show a similar analysis for the case of Customer Relationship Man- 
agement software $(C R M)$ and Business-to-Business applications $(B 2 B)$, respectively. ${ }^{7}$ Regarding the impact of the adoption of CRM downstream on the use of CRM at the firm level analyzed in Table 4, the estimates were around zero depending on the specification considered. This result was expected. Firms downstream might use CRM to improve the communication with their clients and not with the firms that supply them and, therefore, their adoption of $C R M$ is likely to be unrelated to the (upstream) firms' use of $C R M$. The estimates showed in Table 5 regarding the impact on the adoption of B2B by German firms of the use of $B 2 B$ of downstream firms showed the expected positive sign ranging from 0.0379 (std. err. 0.1759 ) to 0.3045 (std. err. 0.2090), although the estimates were less precise.

In sum, the presence of adoption externalities in the use of ICT within the intermediate input markets in Germany seems to be confirmed, as predicted by the literature on general purpose technologies (GPT). However, the results presented in Tables 2-5 referred to the downstream dimension of the intermediate input markets. We extend the analysis to consider the case of the upstream dimension. That is, we study whether the use of ICT by a given firm's suppliers affected that firms own's use of ICT. Following the same approach as before, the results are presented in Tables 6-9. In general the results confirm the existence of adoption externalities. The intensity of ICT use of the firms' suppliers seems to positively affect the intensity of ICT adopted at the firm level (Table 6). As before, it is important to control for the existing ICT infrastructure. Regarding alternative ICT applications, the adoption of $S C R, C R M$ and $B 2 B$ upstream positively affect their use for the firms being supplied (Tables 7-9). However, although the estimates are positive, they are statistically significant, as before, only for the case of SCM.

\subsection{ICT and Firm Strategies}

The previous subsection presented empirical evidence suggesting that adoption externalities in the use of ICT are present in the intermediate input markets in Germany. In this subsection we analyze whether such adoption externalities actually have an impact on the firm strategies employed by the sampled firms. In particular, we estimate equation (9) using the extend of IT outsourcing by German firms as our dependent variable, $y_{i, j, t}$. This variable measures the percentage of the internal IT intensive tasks that

\footnotetext{
${ }^{7} B 2 B$ is defined as the use of the internet to sell products to business customers.
} 
are outsourced. As before, we are interested in the impact of the use of ICT within the intermediate input markets measured by $I C T_{U, t-1}$ and, therefore, focus the attention on the estimates for the parameter $\beta_{1}$ in equation (9).

Table 10 estimates the impact of the intensity of ICT use upstream on the extend of IT outsourcing at the firm level. Column (1) presents the results of a basic specification and shows a negative impact (coef. -0,1649; std. err. 0.1101). However, the estimate is not very precise and cannot be interpreted as statistically different from zero. Note that this result is maintained when alternative variables that measure the ICT infrastructure within the surveyed firms are introduced in the analysis, as well as addition firm-specific control variables in Columns (2)-(6). Interpreting this result cautiously, even though it is not significant, it hints at a negative relationship between the use of ICT by a firm's suppliers (i.e. upstream) and that firm's extend of IT outsourcing. In words, the more ICT intensive a firm's suppliers are, the less IT outsourcing that firms require. Interestingly, this result suggests a substitution effect between inputs provided by suppliers with an intense use of ICT and a firm's demand for external IT services.

To analyze this result further, we consider in Table 11 the role of a firm's suppliers adoption of Supply Chain Management software (SCM) in affecting the extent of IT outsourcing at the firm level. The result presented in Table 10 is confirmed. Moreover, the impact is statistically significant and appears to be robust across alternative specifications. The estimated coefficient varies from -0.3866 (std. err. 0.1664) in Column (4) to -0.4068 (std. err. 0.1637) in Column (1). Table 12 and Table 13 consider the case of Customer Relationship Management software (CRM) and Business-to-Business application (B2B). The results confirmed the negative relation between the use of ICT upstream and the extend of IT outsourcing by German firms, although the coefficients were not statistically significant.

\subsection{ICT and Innovation}

Another dimension of the potential impact of knowledge spillovers from the use of ICT refers to the effect on firm performance. In this subsection we analyze whether the presence of adoption externalities and the existence of knowledge spillovers that affect firm strategies also affect the firms' innovative output. In particular, we study whether the use of ICT within the intermediate input markets (downstream and upstream) in- 
fluenced the value of the introduced innovations. We consider the case of the sales generated in 2006 from product innovation introduced between 2004-2006 and the reduction in costs generated in 2006 from process innovation introduced also between 2004-2006.

Tables 14 and 15 show the estimates of equation (9) regarding the impact of the intensity of ICT use downstream (or the firm's clients) on the increase in sales from product innovations and reduction in costs from process innovations as our dependent variables $y_{i . j, t}$, respectively. The results show that the intensity of ICT use downstream positively affect the reduction in costs (from the introduction of process innovations) but has no effect on the increase in sales (from the introduction of product innovations). Tables 16 and 17 consider the upstream case and find, analogously, a positive effect only on the reduction of costs (from the introduction of process innovations). This result is robust across alternative specifications and suggests that the use of ICT within the intermediate input markets positively affect the efficiency of internal processes as suggested by the literature on general purpose technologies (GPT).

\section{Conclusions}

This paper studies the impact of the adoption of ICT on economic performance at the firm level, considering explicitly the interaction of adopting firms with their clients and suppliers (i.e. downstream and upstream) in a particular segment of the economy: the intermediate input market. The main objective was to identify and quantify the importance of the adoption externalities and knowledge spillovers inherent in the introduction of ICT within the German intermediate input market, their impact on observed firms' strategies and their overall effect on firm performance. The paper finds strong evidence of adoption externalities. That is, the adoption of ICT at the firm level is positively affected by the use of ICT downstream and upstream (i.e. by a firm's clients and suppliers).

Moreover, regarding the role of knowledge spillovers the paper shows that the use of ICT upstream (i.e. by a firm's suppliers) negatively affects the extend of IT outsourcing at the firm level, suggesting a substitution effect between inputs provided by suppliers with an intense use of ICT and a firm's demand for external IT services. The paper also finds that the use of ICT within the intermediate input markets positively affects 
the efficiency of internal processes by increasing the cost reductions generated by the introduction of process innovations. 


\section{References}

Acemoglu, D., P. Aghion, F. Zilibotti, 2003, Distance to Frontier and Vertical Integration, Journal of the European Economic Association, 1, 630-38.

Acemoglu, D., P. Aghion, F. Zilibotti, 2006, Distance to Frontier, Selection, and Economic Growth, Journal of the European Economic Association, 4, 37-74.

Acemoglu D., Aghion P., Lelarge C., Van Reenen, J. and F. Zilibotti, 2007, Technology, Information, and the Decentralization of the Firm, Quarterly Journal of Economics, 122 (4), 1759-99.

Aghion, P., N. Bloom, R. Blundell, R. Griffith and P. Howitt, 2005, Competition and Innovation: An Inverted-U Relationship, Quarterly Journal of Economics, 120, 701728.

Aghion P. and R. Griffith, 2005, Competition and Innovation: Reconciling Theory and Evidence. Zeuthen Lectures. MIT Press.

Aghion, P. and P. Howitt, 1998, On the Macroeconomic Effects of Major Technological Change, in: E. Helpman (ed.), General Purpose Technologies and Economic Growth, MIT Press.

Basu, S., 1995, Intermediate Goods and Business Cycles: Implications for Productivity and Welfare, American Economic Review, 85(3), 512-531. 569-94.

Bloom, N., R. Sadun and J. Van Reenen, 2008, Americans do IT Better: US Multinational and the Productivity Miracle, Working Paper, Stanford University.

Bloom, N., M. Schankerman and J. Van Reenen, 2007, Identifying Technology Spillovers and Product Market Rivalry, NBER Working Paper No. 13060.

Blanchard, O., 2004, The Economic Future of Europe, Journal of Economic Perspectives, Vol. 18, No. 4, 3-26.

Blundell R. and J. Powell, 2007, Censored Regression Quantiles with Endogenous Regressors, Journal of Econometrics, 141, 65-83. 
Bresnahan, T., E. Brynjolfsson and L. Hitt, 2002, Information Technology, Workplace Organization and the Demand for Skilled Labor: Firm-Level Evidence, Quarterly Journal of Economics, 117, 1, 339-76.

Bresnahan, T. and M. Trajtenberg, 1995, General Purpose Technologies: 'Engines of growth?', Journal of Econometrics 65, 83-108.

Brynjolfsson, E. and L. Hitt, 2003, Computing Productivity: Firm Level Evidence, Review of Economics and Statistics, 85, 4, 793-808.

Chun H., J. Kim, R. Morck, B. Yeung, 2008, Creative Destruction and Firm-specific Performance Heterogeneity, Journal of Financial Economics, 89, 109-35.

Ciccone, A., 2002, Input Chains and Industrialization, Review of Economic Studies, 69(3), 565-87.

Crepon, B., E. Duguet and J. Mairesse, 1998, Research, Innovation and Productivity: An Econometric Analysis at the Firm Level, Economics of Innovation and New Technology, 7 (2), 115-58.

David, P.A. and G. Wright, 2003, General Purpose Technologies and Productivity Surges: Historical Reflections on the Future of the ICT Revolution, in: P.A. David and M. Thomas (eds.), The Economic Future in Historical Perspective, Oxford UP.

Draca, M., R. Sadun and J. Van Reenen, 2007, Productivity and ICT: A Review of the Evidence, In Mansell, R., C. Avgerou, D. Quah and R. Silverstone (Eds.), The Oxford Handbook of Information and Communication Technologies, Oxford.

American Economic Review, 98 (1), 394-425.

Griliches, Z., 1995, R\&D and Productivity: Econometric Results and Measurement Issues, in Stoneman, P. (Ed.), Handbook of the Economics of Innovation and Technological Change, Oxford, 52-89.

Hall, B., F. Lotti and J. Mairesse, 2008, Innovation and Productivity in SMES: Empirical Evidence for Italy, NBER Working Paper No. 14594.

Helpman, E., 1998, General Purpose Technologies and Economic Growth, MIT Press.

Helpman, E. and M. Trajtenberg, 1998a, A Time to Sow and a Time to Reap: Growth Based on General Purpose Technologies, in: E. Helpman (ed.), General Purpose Technologies and Economic Growth, MIT Press. 
Helpman, E. and M. Trajtenberg, 1998b, Diffusion of General Purpose Technologies, in: E. Helpman (ed.), General Purpose Technologies and Economic Growth, MIT Press.

Holmstrom, B. and J. Tirole, 1989, The Theory of the Firm, In: Richard Schmalensee and Robert Willig (eds.), Handbook of Industrial Organization, Vol. 1, NorthHolland, Amsterdam.

Hornstein, A. and J. Praschnik, 1997, Intermediate Inputs and Sectoral Comovements in the Business Cycle, Journal of Monetary Economics, 40, 573-95.

Jones, C., 2011, Intermediate Goods and Weak Links: A Theory of Economic Development, American Economic Journal: Macroeconomics, 3(2), 1-28.

Jorgenson, D., M. Ho and K. Stiroh, 2008, A Retrospective Look at the U.S Productivity Growth Resurgence, Journal of Economic Perspectives. 22, 1, 3-24.

Jovanovic, B. and P. L. Rousseau, 2005, General Purpose Technologies, in: Philippe Aghion and Steven Durlauf (eds.), Handbook of Economic Growth, Edition 1, Vol.1, chapter 18, 1181-1224.

Joskow, P., 2006, Vertical Integration, MIT Working Paper.

Katz, M., 1989, Vertical Contractual Relations, In: Richard Schmalensee and Robert Willig (eds.), Handbook of Industrial Organization, Vol. 1, North-Holland, Amsterdam.

Kim, K. and Y. Kim, 2006, How Important is the Intermediate Input Channel in Explaining Sectoral Employment Comovement Over the Business Cycle, Review of Economic Dynamics, 9,659-682.

Lipsey, R. E., Carlaw, K. I. and C. T. Bekar, 2005, Economic Transformations. General Purpose Technologies and Long Term Economic Growth. Oxford University Press.

Lucas, R. E., 1981, Understanding Business Cycles. Studies in Business Cycle Theory, MIT Press.

Long, J. and C. Plosser, 1983, Real Business Cycles, Journal of Political Economy, 91(1), 39-69. 
Rey, P. and J. Tirole, 2007, A Primer on Foreclosure, In: Mark Armstrong and Robert Porter (eds.), Handbook of Industrial Organization, Vol. 3, North-Holland, Amsterdam.

Syverson, C., 2004, Product Substitutability and Productivity Dispersion, Review of Economics and Statistics, 86 (4), 534-550.

Van Ark, B., M. Timmer and M. O'Mahoney, 2008, The Productivity Gap Between Europe and the United States: Trends and Causes, Journal of Economic Perspectives, $22,1,25-44$. 


\section{Appendix}

Table 1: Summary Statistics 2003 and 2006

\begin{tabular}{|c|c|c|c|c|c|}
\hline Variable & Mean & Std. Dev. & Min. & Max. & Obs. \\
\hline \multicolumn{6}{|l|}{2003} \\
\hline Prop. of Employees working mainly with PC & 0.48 & 0.34 & 0.00 & 1.00 & 4321 \\
\hline Use of Enterprise Resource Planning ( $E R P)$ & 0.65 & 0.48 & 0.00 & 1.00 & 4082 \\
\hline Use of Supply Chain Management (SCM) & 0.44 & 0.50 & 0.00 & 1.00 & 4180 \\
\hline Use of Customer Relationship Management (CRM) & 0.52 & 0.50 & 0.00 & 1.00 & 4335 \\
\hline Use of Business-to-Business $(B 2 B)$ & 0.48 & 0.50 & 0.00 & 1.00 & 4328 \\
\hline Total Employees & 349 & 1,743 & 5.00 & 60,000 & 3989 \\
\hline Gross Investments in (EUR) Mill. & 3.98 & 55.14 & 0.00 & 2,700 & 2841 \\
\hline Prop. of High Qualified Employees & 0.22 & 0.25 & 0.00 & 1.00 & 3624 \\
\hline Subsidiary of a Parent Company & 0.42 & 0.49 & 0.00 & 1.00 & 4019 \\
\hline Export Activity & 0.52 & 0.50 & 0.00 & 1.00 & 4000 \\
\hline Eastern Germany & 0.30 & 0.46 & 0.00 & 1.00 & 6439 \\
\hline \multicolumn{6}{|l|}{2006} \\
\hline Prop. of Employees working mainly with PC & 0.48 & 0.34 & 0.00 & 1.00 & 4275 \\
\hline Use of Enterprise Resource Planning ( $E R P)$ & 0.58 & 0.49 & 0.00 & 1.00 & 4292 \\
\hline Use of Supply Chain Management (SCM) & 0.37 & 0.48 & 0.00 & 1.00 & 4292 \\
\hline Use of Customer Relationship Management (CRM) & 0.47 & 0.50 & 0.00 & 1.00 & 4292 \\
\hline Use of Business-to-Business (B2B) & 0.53 & 0.50 & 0.00 & 1.00 & 4284 \\
\hline Prop. of Outsourced IT Tasks & 0.35 & 0.39 & 0.00 & 1.00 & 4199 \\
\hline Prop. of Sales Increase from Product Inn. 2004-06 & 0.14 & 0.21 & 0.00 & 1.00 & 3710 \\
\hline Prop. of Costs Reduction from Process Inn. 2004-06 & 0.06 & 0.09 & 0.00 & 0.90 & 3426 \\
\hline
\end{tabular}

The sample includes 4,440 observations from each wave of the ZEW-ICT Survey of 2004 and 2006. 
Table 2: Adoption Externalities (Downstream)

Dependent Variable:

Ordinary Least Squares

\% Employees with a PC 2006

(1)

(2)

(3)

(4)

(5)

(6)

\% Employees with PC (Downstream) 0.5211***

\begin{tabular}{|c|c|c|c|c|}
\hline $0.1889^{* * *}$ & $0.1919^{* * *}$ & $0.1829^{* * *}$ & $0.1837^{* * *}$ & $0.1807^{* *}$ \\
\hline$(0.0638)$ & $(0.0637)$ & $(0.0617)$ & $(0.0612)$ & $(0.0609)$ \\
\hline $0.6213^{* * *}$ & $0.6147^{* * *}$ & $0.6094^{* * *}$ & $0.6089^{* * *}$ & $0.6068^{* *}$ \\
\hline \multirow[t]{11}{*}{$(0.0383)$} & $(0.0402)$ & $(0.0409)$ & $(0.0407)$ & $(0.0409)$ \\
\hline & $0.0366^{* *}$ & $0.0234^{*}$ & $0.0229 *$ & 0.0244 \\
\hline & $(0.0148)$ & $(0.0137)$ & $(0.0136)$ & $(0.0147)$ \\
\hline & & $0.0292^{* *}$ & $0.0290^{* *}$ & $0.0298 * *$ \\
\hline & & $(0.0120)$ & $(0.0120)$ & $(0.0117)$ \\
\hline & & 0.0041 & 0.0035 & 0.0060 \\
\hline & & $(0.0102)$ & $(0.0100)$ & (0.0119) \\
\hline & & & 0.0045 & 0.0055 \\
\hline & & & $(0.0179)$ & $(0.0174)$ \\
\hline & & & & -0.0024 \\
\hline & & & & (0.0049) \\
\hline $0.0943^{* * *}$ & $0.0788^{* *}$ & $0.0730^{* *}$ & $0.0706^{* *}$ & $0.0796^{* *}$ \\
\hline$(0.0295)$ & $(0.0305)$ & $(0.0298)$ & $(0.0329)$ & $(0.0374)$ \\
\hline 0.62 & 0.62 & 0.62 & 0.62 & 0.62 \\
\hline 1595 & 1595 & 1595 & 1595 & 1595 \\
\hline
\end{tabular}

All explanatory variables correspond to 2003. Robust standard errors allowing for intra-industry correlation.

Industry dummies included. ${ }^{* * *}$ Significance at $1 \% .{ }^{* *}$ Significance at $5 \% .{ }^{*}$ Significance at $10 \%$. 
Table 3: Adoption Externalities (Downstream)

\section{Dependent Variable:}

Ordinary Least Squares

Supply Chain Management 2006

(1)

(2)

(3)

(4)

(5)

(6)

Supply Chain Management (Downstream) $0.7840^{* * *}$

\begin{tabular}{|c|c|c|c|c|}
\hline $0.7876^{* * *}$ & $0.6360^{* * *}$ & $0.6006^{* * *}$ & $0.5493^{* * *}$ & $0.5337^{* * *}$ \\
\hline$(0.1473)$ & $(0.1405)$ & $(0.1446)$ & $(0.1446)$ & $(0.1577)$ \\
\hline $0.1264^{* *}$ & 0.0663 & 0.0382 & 0.0291 & $0.0855^{* *}$ \\
\hline \multirow[t]{11}{*}{ (0.0569) } & $(0.0404)$ & $(0.0357)$ & $(0.0328)$ & $(0.0372)$ \\
\hline & $0.3371^{* * *}$ & $0.2535^{* * *}$ & $0.2440^{* * *}$ & $0.2064^{* * *}$ \\
\hline & $(0.0247)$ & $(0.0236)$ & $(0.0240)$ & $(0.0232)$ \\
\hline & & $0.0691^{* * *}$ & $0.0654^{* * *}$ & $0.0482^{* *}$ \\
\hline & & $(0.0211)$ & $(0.0210)$ & $(0.0199)$ \\
\hline & & $0.1744^{* * *}$ & $0.1620^{* * *}$ & $0.0985^{* * *}$ \\
\hline & & $(0.0262)$ & $(0.0277)$ & $(0.0245)$ \\
\hline & & & $0.0954^{* * *}$ & $0.0706^{* *}$ \\
\hline & & & $(0.0323)$ & $(0.0310)$ \\
\hline & & & & $0.0611^{* * *}$ \\
\hline & & & & $(0.0088)$ \\
\hline $0.1233^{* *}$ & 0.0341 & -0.0447 & -0.0778 & $-0.2774^{* * *}$ \\
\hline$(0.0503)$ & $(0.0490)$ & $(0.0523)$ & $(0.0505)$ & $(0.0608)$ \\
\hline 0.07 & 0.17 & 0.21 & 0.21 & 0.24 \\
\hline 1602 & 1602 & 1602 & 1602 & 1602 \\
\hline
\end{tabular}

All explanatory variables correspond to 2003. Robust standard errors allowing for intra-industry correlation.

Industry dummies included. ${ }^{* * *}$ Significance at $1 \% .{ }^{* *}$ Significance at $5 \% .{ }^{*}$ Significance at $10 \%$. 
Table 4: Adoption Externalities (Downstream)

\section{Dependent Variable:}

Ordinary Least Squares

Customer Relationship Management 2006

(1)

(2)

(3)

(4)

$(5)$

(6)

\begin{tabular}{|c|c|c|c|c|c|c|}
\hline \multirow[t]{2}{*}{ Customer Relationship Management (Downstream) } & 0.1774 & 0.1055 & -0.0448 & -0.0283 & -0.0410 & 0.0102 \\
\hline & $(0.2036)$ & $(0.1975)$ & $(0.1518)$ & $(0.1410)$ & $(0.1416)$ & $(0.1366)$ \\
\hline \multirow[t]{2}{*}{ \% Employees with PC } & & $0.2313^{* * *}$ & $0.1309^{* *}$ & $0.1192^{* *}$ & $0.1118^{* *}$ & $0.1605^{* * *}$ \\
\hline & & $(0.0672)$ & $(0.0539)$ & $(0.0491)$ & $(0.0469)$ & $(0.0485)$ \\
\hline \multirow[t]{2}{*}{ Customer Relationship Management } & & & $0.3973^{* * *}$ & $0.3342^{* * *}$ & $0.3309^{* * *}$ & $0.3150^{* * *}$ \\
\hline & & & $(0.0292)$ & $(0.0324)$ & $(0.0322)$ & $(0.0308)$ \\
\hline \multirow[t]{2}{*}{ Supply Chain Management } & & & & $0.0708^{* *}$ & $0.0621^{* *}$ & 0.0289 \\
\hline & & & & $(0.0306)$ & $(0.0296)$ & $(0.0296)$ \\
\hline \multirow[t]{2}{*}{ Integrated Controlling Software } & & & & $0.1083^{* * *}$ & $0.0973^{* * *}$ & 0.0413 \\
\hline & & & & $(0.0298)$ & $(0.0308)$ & $(0.0328)$ \\
\hline \multirow[t]{2}{*}{ Export Activity } & & & & & $0.0832^{* * *}$ & $0.0606^{* *}$ \\
\hline & & & & & $(0.0299)$ & $(0.0284)$ \\
\hline \multirow[t]{2}{*}{ Total Employees (in Logs.) } & & & & & & $0.0541^{* * *}$ \\
\hline & & & & & & $(0.0079)$ \\
\hline \multirow[t]{2}{*}{ Constant } & $0.4555^{* * *}$ & $0.3945^{* * *}$ & $0.2863^{* * *}$ & $0.2184^{* * *}$ & $0.1805^{* *}$ & -0.0165 \\
\hline & $(0.0859)$ & $(0.0868)$ & $(0.0771)$ & $(0.0716)$ & $(0.0698)$ & $(0.0722)$ \\
\hline$R^{2}$ & 0.06 & 0.08 & 0.22 & 0.24 & 0.24 & 0.26 \\
\hline Observations & 1602 & 1602 & 1602 & 1602 & 1602 & 1602 \\
\hline
\end{tabular}

All explanatory variables correspond to 2003. Robust standard errors allowing for intra-industry correlation.

Industry dummies included. ${ }^{* * *}$ Significance at $1 \% .{ }^{* *}$ Significance at $5 \% .{ }^{*}$ Significance at $10 \%$. 
Table 5: Adoption Externalities (Downstream)

\section{Dependent Variable:}

Ordinary Least Squares

Business to Business Systems 2006

(1)

(2)

(3)

(4)

(5)

(6)

\begin{tabular}{|c|c|c|c|c|c|c|}
\hline \multirow[t]{2}{*}{ Business to Business Systems (Downstream) } & 0.3045 & 0.0743 & 0.0694 & 0.0460 & 0.0278 & 0.0379 \\
\hline & $(0.2090)$ & $(0.1820)$ & $(0.1781)$ & $(0.1749)$ & $(0.1729)$ & $(0.1759)$ \\
\hline \multirow[t]{2}{*}{ \% Employees with PC } & & $0.1209^{* *}$ & $0.1087^{* *}$ & $0.0949 * *$ & $0.0878^{*}$ & $0.1090^{* *}$ \\
\hline & & $(0.0465)$ & $(0.0468)$ & $(0.0455)$ & $(0.0439)$ & $(0.0431)$ \\
\hline \multirow[t]{2}{*}{ Business to Business Systems } & & $0.2798^{* * *}$ & $0.2693^{* * *}$ & $0.2610^{* * *}$ & $0.2545^{* * *}$ & $0.2556^{* * *}$ \\
\hline & & $(0.0280)$ & $(0.0277)$ & $(0.0291)$ & $(0.0288)$ & $(0.0293)$ \\
\hline \multirow[t]{2}{*}{ Supply Chain Management } & & & $0.0786^{* * *}$ & 0.0395 & 0.0304 & 0.0162 \\
\hline & & & $(0.0232)$ & $(0.0267)$ & $(0.0277)$ & $(0.0285)$ \\
\hline \multirow[t]{2}{*}{ Customer Relationship Management } & & & & $0.0592^{* *}$ & $0.0567^{* *}$ & $0.0500^{*}$ \\
\hline & & & & $(0.0274)$ & $(0.0281)$ & $(0.0285)$ \\
\hline \multirow[t]{2}{*}{ Integrated Controlling Software } & & & & $0.0504^{*}$ & 0.0388 & 0.0147 \\
\hline & & & & $(0.0287)$ & $(0.0273)$ & $(0.0283)$ \\
\hline \multirow[t]{2}{*}{ Export Activity } & & & & & $0.0901^{* * *}$ & $0.0804^{* * *}$ \\
\hline & & & & & $(0.0274)$ & $(0.0256)$ \\
\hline \multirow[t]{2}{*}{ Total Employees (in Logs.) } & & & & & & $0.0230^{* * *}$ \\
\hline & & & & & & $(0.0078)$ \\
\hline \multirow[t]{2}{*}{ Constant } & $0.4249^{* * *}$ & $0.3224^{* * *}$ & $0.2972^{* * *}$ & $0.2731^{* * *}$ & $0.2357^{* * *}$ & $0.1552^{* *}$ \\
\hline & $(0.0823)$ & $(0.0719)$ & $(0.0701)$ & $(0.0709)$ & $(0.0678)$ & $(0.0708)$ \\
\hline$R^{2}$ & 0.03 & 0.12 & 0.12 & 0.13 & 0.13 & 0.14 \\
\hline Observations & 1595 & 1595 & 1595 & 1595 & 1595 & 1595 \\
\hline
\end{tabular}

All explanatory variables correspond to 2003. Robust standard errors allowing for intra-industry correlation. Industry dummies included. ${ }^{* * *}$ Significance at $1 \% .{ }^{* *}$ Significance at $5 \% .{ }^{*}$ Significance at $10 \%$. 
Table 6: Adoption Externalities (Upstream)

\section{Dependent Variable:}

\% Employees with PC 2006

Ordinary Least Squares

(1)

(2)

(3)

(4)

(5)

(6)

\begin{tabular}{|c|c|c|c|c|c|c|}
\hline \multirow[t]{2}{*}{ \% Employees with PC (Upstream) } & $0.4986^{* * *}$ & $0.1740^{* * *}$ & $0.1621^{* * *}$ & $0.1655^{* * *}$ & $0.1664^{* * *}$ & $0.1647^{* * *}$ \\
\hline & $(0.1096)$ & $(0.0617)$ & $(0.0593)$ & $(0.0599)$ & $(0.0594)$ & $(0.0587)$ \\
\hline \multirow[t]{2}{*}{ \% Employees with PC } & & $0.6223^{* * *}$ & $0.6128^{* * *}$ & $0.6107^{* * *}$ & $0.6101^{* * *}$ & $0.6074 * * *$ \\
\hline & & $(0.0383)$ & $(0.0398)$ & $(0.0407)$ & $(0.0405)$ & $(0.0409)$ \\
\hline \multirow[t]{2}{*}{ Customer Relationship Management } & & & $0.0396^{* * *}$ & $0.0297^{* *}$ & $0.0295^{* *}$ & $0.0304^{* *}$ \\
\hline & & & $(0.0130)$ & $(0.0121)$ & $(0.0121)$ & $(0.0118)$ \\
\hline \multirow[t]{2}{*}{ Supply Chain Management } & & & & 0.0231 & 0.0226 & 0.0245 \\
\hline & & & & $(0.0138)$ & $(0.0137)$ & $(0.0147)$ \\
\hline \multirow[t]{2}{*}{ Integrated Controlling Software } & & & & 0.0031 & 0.0024 & 0.0056 \\
\hline & & & & $(0.0101)$ & $(0.0098)$ & $(0.0119)$ \\
\hline \multirow[t]{2}{*}{ Export Activity } & & & & & 0.0047 & 0.0060 \\
\hline & & & & & $(0.0179)$ & $(0.0174)$ \\
\hline \multirow[t]{2}{*}{ Total Employees (in Logs.) } & & & & & & -0.0031 \\
\hline & & & & & & $(0.0048)$ \\
\hline \multirow[t]{2}{*}{ Constant } & $0.1869^{* * *}$ & $0.0867^{* *}$ & $0.0754^{* *}$ & $0.0672^{* *}$ & $0.0645^{*}$ & $0.0754^{*}$ \\
\hline & $(0.0559)$ & $(0.0326)$ & $(0.0315)$ & $(0.0326)$ & $(0.0361)$ & (0.0399) \\
\hline$R^{2}$ & 0.38 & 0.62 & 0.62 & 0.62 & 0.62 & 0.62 \\
\hline Observations & 1595 & 1595 & 1595 & 1595 & 1595 & 1595 \\
\hline
\end{tabular}

All explanatory variables correspond to 2003. Robust standard errors allowing for intra-industry correlation. Industry dummies included. ${ }^{* * *}$ Significance at $1 \% .{ }^{* *}$ Significance at $5 \% .{ }^{*}$ Significance at $10 \%$. 
Table 7: Adoption Externalities (Upstream)

\section{Dependent Variable:}

Ordinary Least Squares

Supply Chain Management 2006

(1)

$(2)$

(3)

(4)

\begin{tabular}{|c|c|c|c|c|c|c|}
\hline Supply Chain Management (Upstream) & $\begin{array}{c}1.0392^{* * *} \\
(0.2084)\end{array}$ & $\begin{array}{c}1.0364^{* * *} \\
(0.2135)\end{array}$ & $\begin{array}{c}0.8638^{* * *} \\
(0.2206)\end{array}$ & $\begin{array}{c}0.7298^{* * *} \\
(0.2040)\end{array}$ & $\begin{array}{c}0.6488^{* * *} \\
(0.2085)\end{array}$ & $\begin{array}{c}0.6507^{* * *} \\
(0.2302)\end{array}$ \\
\hline \% Employees with PC & & $\begin{array}{c}0.1237^{* *} \\
(0.0558)\end{array}$ & $\begin{array}{c}0.0658 \\
(0.0477)\end{array}$ & $\begin{array}{c}0.0367 \\
(0.0353)\end{array}$ & $\begin{array}{c}0.0277 \\
(0.0326)\end{array}$ & $\begin{array}{l}0.0846^{* *} \\
(0.0369)\end{array}$ \\
\hline Customer Relationship Management & & & $\begin{array}{c}0.2202^{* * *} \\
(0.0243)\end{array}$ & $\begin{array}{c}0.0662^{* * *} \\
(0.0212)\end{array}$ & $\begin{array}{c}0.0628^{* * *} \\
(0.0211)\end{array}$ & $\begin{array}{l}0.0455^{* *} \\
(0.0201)\end{array}$ \\
\hline Supply Chain Management & & & & $\begin{array}{c}0.2556^{* * *} \\
(0.0239)\end{array}$ & $\begin{array}{c}0.2460^{* * *} \\
(0.0243)\end{array}$ & $\begin{array}{c}0.2081^{* * *} \\
(0.0235)\end{array}$ \\
\hline Integrated Controlling Software & & & & $\begin{array}{c}0.1734^{* * *} \\
(0.0261)\end{array}$ & $\begin{array}{c}0.1612^{* * *} \\
(0.0276)\end{array}$ & $\begin{array}{c}0.0972^{* * *} \\
(0.0241)\end{array}$ \\
\hline Export Activity & & & & & $\begin{array}{c}0.0953^{* * *} \\
(0.0325)\end{array}$ & $\begin{array}{c}0.0700^{* *} \\
(0.0313)\end{array}$ \\
\hline Total Employees (in Logs.) & & & & & & $\begin{array}{c}0.0615^{* * *} \\
(0.0087)\end{array}$ \\
\hline Constant & $\begin{array}{l}0.1450^{* *} \\
(0.0618)\end{array}$ & $\begin{array}{c}0.1003 \\
(0.0662)\end{array}$ & $\begin{array}{c}0.0563 \\
(0.0744)\end{array}$ & $\begin{array}{l}-0.0463 \\
(0.0678)\end{array}$ & $\begin{array}{l}-0.0748 \\
(0.0654)\end{array}$ & $\begin{array}{c}-0.2807^{* * *} \\
(0.0757)\end{array}$ \\
\hline$R^{2}$ & 0.06 & 0.07 & 0.11 & 0.20 & 0.21 & 0.24 \\
\hline Observations & 1602 & 1602 & 1602 & 1602 & 1602 & 1602 \\
\hline
\end{tabular}

All explanatory variables correspond to 2003. Robust standard errors allowing for intra-industry correlation.

Industry dummies included. ${ }^{* * *}$ Significance at $1 \% .{ }^{* *}$ Significance at $5 \% .{ }^{*}$ Significance at $10 \%$. 
Table 8: Adoption Externalities (Upstream)

\section{Dependent Variable:}

Ordinary Least Squares

Customer Relationship Management 2006

(1)

(2)

(6)

\begin{tabular}{|c|c|c|c|c|c|c|}
\hline Customer Relationship Management (Upstream) & $0.4239 *$ & 0.3257 & 0.0997 & 0.1055 & 0.0959 & 0.1501 \\
\hline & $(0.2310)$ & $(0.2311)$ & $(0.1944)$ & $(0.1847)$ & $(0.1851)$ & $(0.1819)$ \\
\hline \% Employees with PC & & $0.2242^{* * *}$ & $0.1269^{* *}$ & $0.1155^{* *}$ & $0.1081^{* *}$ & $0.1570^{* * *}$ \\
\hline & & $(0.0688)$ & $(0.0548)$ & $(0.0496)$ & $(0.0474)$ & $(0.0490)$ \\
\hline Customer Relationship Management & & & $0.3955^{* * *}$ & $0.3324^{* * *}$ & $0.3291^{* * *}$ & $0.3131^{* * *}$ \\
\hline & & & $(0.0294)$ & $(0.0325)$ & $(0.0322)$ & $(0.0308)$ \\
\hline Supply Chain Management & & & & $0.0711^{* *}$ & $0.0625^{* *}$ & 0.0290 \\
\hline & & & & $(0.0305)$ & $(0.0296)$ & $(0.0296)$ \\
\hline Integrated Controlling Software & & & & $0.1083^{* * *}$ & $0.0975^{* * *}$ & 0.0408 \\
\hline & & & & $(0.0299)$ & $(0.0308)$ & $(0.0329)$ \\
\hline Export Activity & & & & & $0.0826^{* * *}$ & $0.0599^{* *}$ \\
\hline & & & & & $(0.0298)$ & $(0.0284)$ \\
\hline Total Employees (in Logs.) & & & & & & $0.0545^{* * *}$ \\
\hline & & & & & & $(0.0078)$ \\
\hline Constant & $0.3725^{* * *}$ & $0.3231^{* * *}$ & $0.2403^{* * *}$ & $0.1757^{* *}$ & $0.1372^{*}$ & -0.0621 \\
\hline & $(0.0939)$ & $(0.0930)$ & $(0.0854)$ & $(0.0786)$ & $(0.0771)$ & $(0.0794)$ \\
\hline$R^{2}$ & 0.06 & 0.08 & 0.22 & 0.24 & 0.24 & 0.26 \\
\hline Observations & 1602 & 1602 & 1602 & 1602 & 1602 & 1602 \\
\hline
\end{tabular}

All explanatory variables correspond to 2003. Robust standard errors allowing for intra-industry correlation.

Industry dummies included. ${ }^{* * *}$ Significance at $1 \% .{ }^{* *}$ Significance at $5 \% .{ }^{*}$ Significance at $10 \%$. 
Table 9: Adoption Externalities (Upstream)

Dependent Variable:

Ordinary Least Squares

Business to Business Systems

(1)

(2)

(3)

(4)

\begin{tabular}{|c|c|c|c|c|c|c|}
\hline Business to Business Systems (Upstream) & $\begin{array}{l}0.3422^{*} \\
(0.1750)\end{array}$ & $\begin{array}{c}0.0818 \\
(0.1430)\end{array}$ & $\begin{array}{c}0.0395 \\
(0.1388)\end{array}$ & $\begin{array}{c}0.0354 \\
(0.1375)\end{array}$ & $\begin{array}{c}0.0173 \\
(0.1389)\end{array}$ & $\begin{array}{c}0.0207 \\
(0.1435)\end{array}$ \\
\hline \% Employees with PC & & $\begin{array}{c}0.1205^{* *} \\
(0.0459)\end{array}$ & $\begin{array}{l}0.1002^{* *} \\
(0.0455)\end{array}$ & $\begin{array}{l}0.0950 * * \\
(0.0448)\end{array}$ & $\begin{array}{c}0.0880^{* *} \\
(0.0433)\end{array}$ & $\begin{array}{l}0.1092^{* *} \\
(0.0425)\end{array}$ \\
\hline Business to Business Systems & & $\begin{array}{c}0.2798^{* * *} \\
(0.0278)\end{array}$ & $\begin{array}{c}0.2648^{* * *} \\
(0.0294)\end{array}$ & $\begin{array}{c}0.2612^{* * *} \\
(0.0289)\end{array}$ & $\begin{array}{c}0.2547^{* * *} \\
(0.0286)\end{array}$ & $\begin{array}{c}0.2559^{* * *} \\
(0.0291)\end{array}$ \\
\hline Customer Relationship Management & & & $\begin{array}{c}0.0904^{* * *} \\
(0.0236)\end{array}$ & $\begin{array}{l}0.0593^{* *} \\
(0.0278)\end{array}$ & $\begin{array}{l}0.0568 * \\
(0.0285)\end{array}$ & $\begin{array}{l}0.0502^{*} \\
(0.0289)\end{array}$ \\
\hline Supply Chain Management & & & & $\begin{array}{c}0.0395 \\
(0.0268)\end{array}$ & $\begin{array}{c}0.0303 \\
(0.0278)\end{array}$ & $\begin{array}{c}0.0161 \\
(0.0286)\end{array}$ \\
\hline Integrated Controlling Software & & & & $\begin{array}{l}0.0502^{*} \\
(0.0287)\end{array}$ & $\begin{array}{c}0.0387 \\
(0.0273)\end{array}$ & $\begin{array}{c}0.0147 \\
(0.0282)\end{array}$ \\
\hline Export Activity & & & & & $\begin{array}{c}0.0902^{* * *} \\
(0.0272)\end{array}$ & $\begin{array}{c}0.0806^{* * *} \\
(0.0253)\end{array}$ \\
\hline Total Employees (in Logs.) & & & & & & $\begin{array}{c}0.0230^{* * *} \\
(0.0077)\end{array}$ \\
\hline Constant & $\begin{array}{c}0.3983^{* * *} \\
(0.0779)\end{array}$ & $\begin{array}{c}0.3166^{* * *} \\
(0.0709)\end{array}$ & $\begin{array}{c}0.3031^{* * *} \\
(0.0701)\end{array}$ & $\begin{array}{c}0.2752^{* * *} \\
(0.0704)\end{array}$ & $\begin{array}{c}0.2383^{* * *} \\
(0.0692)\end{array}$ & $\begin{array}{l}0.1600^{* *} \\
(0.0722)\end{array}$ \\
\hline$R^{2}$ & 0.03 & 0.12 & 0.12 & 0.13 & 0.13 & 0.14 \\
\hline Observations & 1595 & 1595 & 1595 & 1595 & 1595 & 1595 \\
\hline
\end{tabular}

All explanatory variables correspond to 2003. Robust standard errors allowing for intra-industry correlation. Industry dummies included. ${ }^{* * *}$ Significance at $1 \% .{ }^{* *}$ Significance at $5 \% .{ }^{*}$ Significance at $10 \%$. 
Table 10: Firm Strategies (Upstream)

\section{Dependent Variable:}

Ordinary Least Squares

\section{IT Outsourcing}

(1)

(2)

$-0.1214$

(0.1081)

$-0.0835^{*}$

(0.0462)
(3)

$-0.1174$

(0.1080)

$-0.1210$

(0.1083)

$-0.1202$

$-0.1327$

\% Employees with PC

Customer Relationship Management

Supply Chain Management

Integrated Controlling Software

Export Activity

Total Employees (in Logs.)

\begin{tabular}{lcccccc} 
Constant & $0.5487^{* * *}$ & $0.5623^{* * *}$ & $0.5662^{* * *}$ & $0.5743^{* * *}$ & $0.5721^{* * *}$ & $0.6547^{* * *}$ \\
& $(0.0520)$ & $(0.0520)$ & $(0.0533)$ & $(0.0550)$ & $(0.0587)$ & $(0.0594)$ \\
$R^{2}$ & 0.08 & 0.08 & 0.08 & 0.08 & 0.08 & 0.09 \\
Observations & 1582 & 1582 & 1582 & 1582 & 1582 & 1582 \\
\hline
\end{tabular}

All explanatory variables correspond to 2003. Robust standard errors allowing for intra-industry correlation. Industry dummies included. ${ }^{* * *}$ Significance at $1 \% .{ }^{* *}$ Significance at $5 \% .{ }^{*}$ Significance at $10 \%$. 
Table 11: Firm Strategies (Upstream)

\section{Dependent Variable:}

Ordinary Least Squares

\section{IT Outsourcing 2006}
(1)
$(2)$
(3)
(4)
(5)
(6)

\begin{tabular}{|c|c|c|c|c|c|c|}
\hline Supply Chain Management (Upstream & $-0.4068^{* *}$ & $-0.4025^{* *}$ & $-0.3939 * *$ & $-0.3866^{* *}$ & $-0.3996^{* *}$ & \\
\hline & $(0.1637)$ & $(0.1626)$ & $(0.1652)$ & $(0.1664)$ & $(0.1746)$ & \\
\hline \% Employees with PC & & $-0.0909 *$ & $-0.0879 *$ & $-0.0864^{*}$ & $-0.1081^{* *}$ & $-0.1069 * *$ \\
\hline & & $(0.0453)$ & $(0.0439)$ & $(0.0434)$ & $(0.0438)$ & $(0.0442)$ \\
\hline Customer Relationship Management & & & -0.0112 & -0.0030 & 0.0032 & 0.0005 \\
\hline & & & $(0.0172)$ & $(0.0196)$ & $(0.0210)$ & $(0.0207)$ \\
\hline Supply Chain Management & & & & -0.0212 & -0.0081 & -0.0095 \\
\hline & & & & $(0.0279)$ & $(0.0270)$ & $(0.0271)$ \\
\hline Integrated Controlling Software & & & & -0.0002 & 0.0222 & 0.0214 \\
\hline & & & & $(0.0208)$ & $(0.0213)$ & $(0.0215)$ \\
\hline Export Activity & & & & & 0.0208 & 0.0145 \\
\hline & & & & & $(0.0241)$ & $(0.0238)$ \\
\hline Total Employees (in Logs.) & & & & & $-0.0231^{* *}$ & $-0.0230^{* *}$ \\
\hline & & & & & $(0.0104)$ & $(0.0106)$ \\
\hline Constant & $0.5849^{* * *}$ & $0.6172^{* * *}$ & $0.6195^{* * *}$ & $0.6231^{* * *}$ & $0.6975^{* * *}$ & $0.6038^{* * *}$ \\
\hline & $(0.0494)$ & $(0.0526)$ & $(0.0532)$ & $(0.0534)$ & $(0.0563)$ & $(0.0489)$ \\
\hline$R^{2}$ & 0.08 & 0.09 & 0.09 & 0.09 & 0.09 & 0.09 \\
\hline Observations & 1582 & 1582 & 1582 & 1582 & 1582 & 1582 \\
\hline
\end{tabular}

All explanatory variables correspond to 2003. Robust standard errors allowing for intra-industry correlation. Industry dummies included. ${ }^{* * *}$ Significance at $1 \% .{ }^{* *}$ Significance at $5 \% .{ }^{*}$ Significance at $10 \%$. 
Table 12: Firm Strategies (Upstream)

\section{Dependent Variable:}

Ordinary Least Squares

\section{IT Outsourcing 2006}

(1)

(2)

(0.1488)

$-0.0867^{*}$

(0.0459)

(0.1546)

$-0.1522$

$-0.1541$

$-0.1786$

\% Employees with a PC

Customer Relationship Management

Supply Chain Management

Integrated Controlling Software

Export Activity

Total Employees (in Logs.)

\begin{tabular}{lccccccc} 
Constant & $0.5499^{* * *}$ & $0.5689^{* * *}$ & $0.5718^{* * *}$ & $0.5789^{* * *}$ & $0.6621^{* * *}$ & $0.6038^{* * *}$ \\
& $(0.0580)$ & $(0.0577)$ & $(0.0584)$ & $(0.0600)$ & $(0.0599)$ & $(0.0489)$ \\
$R^{2}$ & 0.08 & 0.08 & 0.08 & 0.08 & 0.09 & 0.09 \\
Observations & 1582 & 1582 & 1582 & 1582 & 1582 & 1582 \\
\hline
\end{tabular}

All explanatory variables correspond to 2003. Robust standard errors allowing for intra-industry correlation.

Industry dummies included. ${ }^{* * *}$ Significance at $1 \%$. ${ }^{* *}$ Significance at $5 \%$. ${ }^{*}$ Significance at $10 \%$. 
Table 13: Firm Strategies (Downstream)

\section{Dependent Variable:}

Ordinary Least Squares

IT Outsourcing

(1)

(2)

(3)

(4)

(5)

(6)

\begin{tabular}{|c|c|c|c|c|c|c|}
\hline \multirow[t]{2}{*}{ Business to Business Systems (Downstream) } & -0.1929 & -0.1540 & -0.1507 & -0.1520 & -0.1535 & -0.1656 \\
\hline & $(0.1196)$ & $(0.1142)$ & $(0.1153)$ & $(0.1166)$ & $(0.1166)$ & $(0.1196)$ \\
\hline \multirow[t]{2}{*}{ \% Employees with PC } & & $-0.0831^{*}$ & $-0.0809^{*}$ & $-0.0794^{*}$ & $-0.0801^{*}$ & $-0.1005^{* *}$ \\
\hline & & $(0.0463)$ & $(0.0448)$ & $(0.0445)$ & $(0.0445)$ & $(0.0447)$ \\
\hline \multirow[t]{2}{*}{ Business to Business Systems } & & -0.0192 & -0.0176 & -0.0161 & -0.0167 & -0.0179 \\
\hline & & $(0.0157)$ & $(0.0169)$ & $(0.0167)$ & $(0.0169)$ & $(0.0165)$ \\
\hline \multirow[t]{2}{*}{ Customer Relationship Management } & & & -0.0095 & -0.0007 & -0.0010 & 0.0059 \\
\hline & & & $(0.0184)$ & $(0.0211)$ & $(0.0211)$ & $(0.0224)$ \\
\hline \multirow[t]{2}{*}{ Supply Chain Management } & & & & -0.0218 & -0.0226 & -0.0082 \\
\hline & & & & $(0.0282)$ & $(0.0277)$ & $(0.0272)$ \\
\hline \multirow[t]{2}{*}{ Integrated Controlling Software } & & & & -0.0019 & -0.0031 & 0.0212 \\
\hline & & & & $(0.0206)$ & $(0.0207)$ & $(0.0212)$ \\
\hline \multirow[t]{2}{*}{ Export Activity } & & & & & 0.0086 & 0.0184 \\
\hline & & & & & $(0.0222)$ & $(0.0242)$ \\
\hline \multirow[t]{2}{*}{ Total Employees (in Logs.) } & & & & & & $-0.0233^{* *}$ \\
\hline & & & & & & $(0.0104)$ \\
\hline \multirow[t]{2}{*}{ Constant } & $0.5489^{* * *}$ & $0.5756^{* * *}$ & $0.5776^{* * *}$ & $0.5837^{* * *}$ & $0.5800^{* * *}$ & $0.6618^{* * *}$ \\
\hline & $(0.0477)$ & $(0.0481)$ & $(0.0488)$ & $(0.0517)$ & $(0.0535)$ & $(0.0579)$ \\
\hline$R^{2}$ & 0.08 & 0.08 & 0.08 & 0.08 & 0.08 & 0.09 \\
\hline Observations & 1579 & 1579 & 1579 & 1579 & 1579 & 1579 \\
\hline
\end{tabular}

All explanatory variables correspond to 2003. Robust standard errors allowing for intra-industry correlation. Industry dummies included. ${ }^{* * *}$ Significance at $1 \% .{ }^{* *}$ Significance at $5 \% .{ }^{*}$ Significance at $10 \%$. 
Table 14: Innovation (Downstream)

\section{Dependent Variable:}

Ordinary Least Squares

Sales with Product Innovations 2006
(1)
(2)
(3)
(4)
(5)
(6)

\begin{tabular}{|c|c|c|c|c|c|c|}
\hline \multirow[t]{2}{*}{ \% Employees with PC (Downstream) } & 0.0771 & 0.0041 & -0.0002 & -0.0031 & 0.0028 & -0.0042 \\
\hline & $(0.0644)$ & $(0.0507)$ & $(0.0511)$ & $(0.0518)$ & $(0.0528)$ & $(0.0526)$ \\
\hline \multirow[t]{2}{*}{ Product Innovation } & & $0.1062^{* * *}$ & $0.1038^{* * *}$ & $0.1056^{* * *}$ & $0.0999^{* * *}$ & $0.1014^{* * *}$ \\
\hline & & $(0.0150)$ & $(0.0148)$ & $(0.0150)$ & $(0.0153)$ & $(0.0155)$ \\
\hline \multirow[t]{2}{*}{ \% Employees with PC } & & $0.0712^{* * *}$ & $0.0686^{* * *}$ & $0.0692^{* * *}$ & $0.0664^{* * *}$ & $0.0619 * *$ \\
\hline & & $(0.0248)$ & $(0.0252)$ & $(0.0254)$ & $(0.0246)$ & $(0.0251)$ \\
\hline \multirow[t]{2}{*}{ Customer Relationship Management } & & & 0.0118 & 0.0171 & 0.0160 & 0.0172 \\
\hline & & & $(0.0095)$ & $(0.0118)$ & $(0.0119)$ & $(0.0119)$ \\
\hline \multirow[t]{2}{*}{ Supply Chain Management } & & & & -0.0138 & -0.0164 & -0.0134 \\
\hline & & & & $(0.0109)$ & $(0.0104)$ & $(0.0100)$ \\
\hline \multirow[t]{2}{*}{ Integrated Controlling Software } & & & & -0.0005 & -0.0043 & 0.0009 \\
\hline & & & & $(0.0121)$ & $(0.0121)$ & $(0.0122)$ \\
\hline \multirow[t]{2}{*}{ Export Activity } & & & & & $0.0317^{* *}$ & $0.0334^{* *}$ \\
\hline & & & & & $(0.0123)$ & $(0.0126)$ \\
\hline \multirow[t]{2}{*}{ Total Employees (in Logs.) } & & & & & & -0.0052 \\
\hline & & & & & & $(0.0031)$ \\
\hline \multirow[t]{2}{*}{ Constant } & $0.0867^{* * *}$ & 0.0204 & 0.0185 & 0.0219 & 0.0062 & 0.0253 \\
\hline & $(0.0267)$ & $(0.0251)$ & $(0.0248)$ & $(0.0257)$ & $(0.0268)$ & $(0.0290)$ \\
\hline$R^{2}$ & 0.08 & 0.14 & 0.14 & 0.15 & 0.15 & 0.15 \\
\hline Observations & 1369 & 1369 & 1369 & 1369 & 1369 & 1369 \\
\hline
\end{tabular}

All explanatory variables correspond to 2003. Robust standard errors allowing for intra-industry correlation.

Industry dummies included. ${ }^{* * *}$ Significance at $1 \% .{ }^{* *}$ Significance at $5 \% .{ }^{*}$ Significance at $10 \%$. 
Table 15: Innovation (Downstream)

Dependent Variable

Ordinary Least Squares

Cost Reduction with Process Innovation 2006

(1)

(2)

(3)

(4)

(5)

(6)

\begin{tabular}{|c|c|c|c|c|c|c|}
\hline \multirow[t]{2}{*}{ \% Employees with PC (Downstream) } & $0.0521^{* * *}$ & $0.0421^{* *}$ & $0.0429^{* *}$ & $0.0444^{* *}$ & $0.0441^{* *}$ & $0.0432^{* *}$ \\
\hline & $(0.0185)$ & $(0.0181)$ & $(0.0184)$ & $(0.0193)$ & $(0.0193)$ & $(0.0195)$ \\
\hline \multirow[t]{2}{*}{ Process Innovation } & & $0.0230^{* * *}$ & $0.0207^{* * *}$ & $0.0192^{* * *}$ & $0.0195^{* * *}$ & $0.0198^{* * *}$ \\
\hline & & $(0.0048)$ & $(0.0049)$ & $(0.0049)$ & $(0.0052)$ & $(0.0054)$ \\
\hline \multirow[t]{2}{*}{ \% Employees with PC } & & 0.0106 & 0.0089 & 0.0078 & 0.0080 & 0.0075 \\
\hline & & $(0.0065)$ & $(0.0068)$ & $(0.0071)$ & $(0.0071)$ & $(0.0073)$ \\
\hline \multirow[t]{2}{*}{ Supply Chain Management } & & & $0.0128^{* * *}$ & 0.0088 & 0.0089 & 0.0092 \\
\hline & & & $(0.0044)$ & $(0.0053)$ & $(0.0053)$ & $(0.0056)$ \\
\hline \multirow[t]{2}{*}{ Customer Relationship Management } & & & & 0.0016 & 0.0017 & 0.0019 \\
\hline & & & & $(0.0054)$ & $(0.0054)$ & $(0.0053)$ \\
\hline \multirow[t]{2}{*}{ Integrated Controlling Software } & & & & $0.0110^{*}$ & $0.0113^{* *}$ & $0.0118^{* *}$ \\
\hline & & & & $(0.0056)$ & $(0.0052)$ & $(0.0051)$ \\
\hline \multirow[t]{2}{*}{ Export Activity } & & & & & -0.0021 & -0.0019 \\
\hline & & & & & $(0.0057)$ & $(0.0055)$ \\
\hline \multirow[t]{2}{*}{ Total Employees (in Logs.) } & & & & & & -0.0006 \\
\hline & & & & & & $(0.0017)$ \\
\hline \multirow[t]{2}{*}{ Constant } & $0.0514^{* * *}$ & $0.0332^{* * *}$ & $0.0294^{* * *}$ & $0.0252^{* *}$ & $0.0262^{* *}$ & $0.0282^{* *}$ \\
\hline & $(0.0106)$ & $(0.0105)$ & $(0.0106)$ & $(0.0109)$ & $(0.0114)$ & $(0.0136)$ \\
\hline$R^{2}$ & 0.03 & 0.04 & 0.05 & 0.05 & 0.05 & 0.05 \\
\hline Observations & 1283 & 1283 & 1283 & 1283 & 1283 & 1283 \\
\hline
\end{tabular}

All explanatory variables correspond to 2003. Robust standard errors allowing for intra-industry correlation.

Industry dummies included. ${ }^{* * *}$ Significance at $1 \% .{ }^{* *}$ Significance at $5 \% .{ }^{*}$ Significance at $10 \%$. 
Table 16: Innovation (Upstream)

\section{Dependent Variable:}

Ordinary Least Squares

Sales with Product Innovations 2006

(1)

(2)

(3)

(4)

(5)

(6)

\begin{tabular}{|c|c|c|c|c|c|c|}
\hline \multirow[t]{2}{*}{ \% Employees with PC (Upstream) } & 0.0694 & 0.0099 & 0.0053 & 0.0031 & 0.0095 & 0.0063 \\
\hline & $(0.0594)$ & $(0.0499)$ & $(0.0499)$ & $(0.0499)$ & $(0.0503)$ & $(0.0491)$ \\
\hline \multirow[t]{2}{*}{ Product Innovation } & & $0.1062^{* * *}$ & $0.1038^{* * *}$ & $0.1055^{* * *}$ & $0.0999 * * *$ & $0.1013^{* * *}$ \\
\hline & & $(0.0149)$ & $(0.0148)$ & $(0.0150)$ & $(0.0153)$ & $(0.0154)$ \\
\hline \multirow[t]{2}{*}{ \% Employees with PC } & & $0.0709^{* * *}$ & $0.0682^{* *}$ & $0.0689^{* *}$ & $0.0660^{* *}$ & $0.0613^{* *}$ \\
\hline & & $(0.0255)$ & $(0.0259)$ & $(0.0261)$ & $(0.0254)$ & $(0.0258)$ \\
\hline \multirow[t]{2}{*}{ Customer Relationship Management } & & & 0.0117 & 0.0169 & 0.0159 & 0.0170 \\
\hline & & & $(0.0094)$ & $(0.0117)$ & $(0.0117)$ & $(0.0117)$ \\
\hline \multirow[t]{2}{*}{ Supply Chain Management } & & & & -0.0137 & -0.0163 & -0.0134 \\
\hline & & & & $(0.0108)$ & $(0.0104)$ & $(0.0100)$ \\
\hline \multirow[t]{2}{*}{ Integrated Controlling Software } & & & & -0.0005 & -0.0043 & 0.0009 \\
\hline & & & & $(0.0121)$ & $(0.0121)$ & $(0.0122)$ \\
\hline \multirow[t]{2}{*}{ Export Activity } & & & & & $0.0318^{* *}$ & $0.0335^{* *}$ \\
\hline & & & & & $(0.0122)$ & $(0.0126)$ \\
\hline \multirow[t]{2}{*}{ Total Employees (in Logs.) } & & & & & & -0.0052 \\
\hline & & & & & & $(0.0031)$ \\
\hline \multirow[t]{2}{*}{ Constant } & $0.0845^{* * *}$ & 0.0180 & 0.0165 & 0.0198 & 0.0035 & 0.0215 \\
\hline & $(0.0302)$ & $(0.0281)$ & $(0.0280)$ & $(0.0287)$ & $(0.0293)$ & $(0.0302)$ \\
\hline$R^{2}$ & 0.08 & 0.14 & 0.14 & 0.15 & 0.15 & 0.15 \\
\hline Observations & 1369 & 1369 & 1369 & 1369 & 1369 & 1369 \\
\hline
\end{tabular}

All explanatory variables correspond to 2003. Robust standard errors allowing for intra-industry correlation.

Industry dummies included. ${ }^{* *}$ Significance at $1 \% .{ }^{* *}$ Significance at $5 \% .{ }^{*}$ Significance at $10 \%$. 
Table 17: Innovation (Upstream)

Dependent Variable

Ordinary Least Squares

Cost Reduction with Process Innovation 2006

(1)

(2)

(3)

(4)

(5)

(6)

\begin{tabular}{|c|c|c|c|c|c|c|}
\hline \multirow[t]{2}{*}{ \% Employees with PC (Upstream) } & $0.0517^{* * *}$ & $0.0409^{* *}$ & $0.0412^{* *}$ & $0.0417^{* *}$ & $0.0414^{* *}$ & $0.0408^{* *}$ \\
\hline & $(0.0176)$ & $(0.0186)$ & $(0.0191)$ & $(0.0200)$ & $(0.0202)$ & $(0.0202)$ \\
\hline \multirow[t]{2}{*}{ Process Innovation } & & $0.0229 * * *$ & $0.0206^{* * *}$ & $0.0192^{* * *}$ & $0.0194^{* * *}$ & $0.0198^{* * *}$ \\
\hline & & $(0.0047)$ & $(0.0048)$ & $(0.0049)$ & $(0.0052)$ & $(0.0054)$ \\
\hline \multirow[t]{2}{*}{ \% Employees with PC } & & 0.0106 & 0.0089 & 0.0079 & 0.0081 & 0.0074 \\
\hline & & $(0.0068)$ & $(0.0070)$ & $(0.0074)$ & $(0.0074)$ & $(0.0075)$ \\
\hline \multirow[t]{2}{*}{ Supply Chain Management } & & & $0.0128^{* * *}$ & 0.0087 & 0.0089 & 0.0093 \\
\hline & & & $(0.0044)$ & $(0.0053)$ & $(0.0053)$ & $(0.0056)$ \\
\hline \multirow[t]{2}{*}{ Customer Relationship Management } & & & & 0.0018 & 0.0019 & 0.0021 \\
\hline & & & & $(0.0053)$ & $(0.0053)$ & $(0.0053)$ \\
\hline \multirow[t]{2}{*}{ Integrated Controlling Software } & & & & $0.0107^{*}$ & $0.0110^{* *}$ & $0.0118^{* *}$ \\
\hline & & & & $(0.0055)$ & $(0.0052)$ & $(0.0051)$ \\
\hline \multirow[t]{2}{*}{ Export Activity } & & & & & -0.0021 & -0.0018 \\
\hline & & & & & $(0.0057)$ & $(0.0055)$ \\
\hline \multirow[t]{2}{*}{ Total Employees (in Logs.) } & & & & & & -0.0008 \\
\hline & & & & & & $(0.0017)$ \\
\hline \multirow[t]{2}{*}{ Constant } & $0.0480^{* * *}$ & $0.0308^{* *}$ & $0.0272^{* *}$ & $0.0233^{*}$ & $0.0244^{*}$ & $0.0269^{*}$ \\
\hline & $(0.0115)$ & $(0.0117)$ & $(0.0119)$ & $(0.0124)$ & $(0.0130)$ & $(0.0151)$ \\
\hline$R^{2}$ & 0.03 & 0.04 & 0.05 & 0.05 & 0.05 & 0.05 \\
\hline Observations & 1283 & 1283 & 1283 & 1283 & 1283 & 1283 \\
\hline
\end{tabular}

All explanatory variables correspond to 2003. Robust standard errors allowing for intra-industry correlation. Industry dummies included. ${ }^{* * *}$ Significance at $1 \% .{ }^{* *}$ Significance at $5 \% .{ }^{*}$ Significance at $10 \%$. 